\title{
Editorial
}

\section{Beyond the Paris Agreement - ambitions, hopes, fears and flaws}

The first global stocktake required under Article 14 of the Paris Agreement will take place in 2023. ${ }^{1}$ In the interim, the contributions to this edition of the Journal of Human Rights and the Environment (JHRE) reflect upon the efficacy of the Agreement since it was negotiated in December 2015. As expected, 2017 is on course to be one of the hottest years on record. ${ }^{2}$ The Agreement contains a ratcheting up mechanism designed to encourage increased ambition from state parties to close the emissions gap between their Nationally Determined Contributions (NDC) and the objective in Article 2 of preventing the average global temperature from increasing by more than $2{ }^{\circ} \mathrm{C}$ above pre-industrial levels and the accompanying exhortation - more consistent with climate science - to limit the increase to no more than $1.5^{\circ} \mathrm{C}$ (necessary to prevent the inundation of several small island developing states). ${ }^{3}$

The Paris Agreement is a flawed document that reflects the compromises necessary to reach agreement in a forum based upon consensus such as the UN Framework Convention on Climate Change (UNFCCC). ${ }^{4}$ Its voluntarist, bottom-up nature means that the Agreement is legally binding but unenforceable, made clear by the Trump administration's intention to withdraw from it (leaving the United States isolated following the signatures of Nicaragua and Syria). What the Agreement gives with one hand it takes away with the other, the most conspicuous example being the first reference to human rights in a legally binding multilateral climate agreement that however appears in the Preamble rather than in the operative part of the text. ${ }^{5}$ Four of the contributions to this issue of the JHRE (by Birrell and Godden, Atapattu, Maguire and Lewis, and Savaresi) view this as a spurned opportunity to include the stronger protection of human rights in earlier drafts of the Agreement. ${ }^{6}$

Developed countries were determined to confine human rights to the Preamble (along with a reference to the importance of the concept of climate justice for some), with the aim of limiting their use to establishing liability through climate

1. UNFCCC, Decision 1/CP.21, Adoption of the Paris Agreement FCCC/CP/2015/10/Add.1 (29 January 2016) (opened for signature on 22 April 2016, entered into force 4 November 2016). 2. World Meteorological Organization, 'WMO Statement on the State of the Global Climate in 2017 ' <https://public.wmo.int/en/wmo-statement-state-of-global-climate-2017> accessed 8 November 2017.

3. United Nations Environment Programme, The Emissions Gap Report 2017 <https://wedocs. unep.org/bitstream/handle/20.500.11822/22070/EGR_2017.pdf?> accessed 13 November 2017.

4. For an extended analysis of the Agreement see S Adelman, 'Human Rights in the Paris Agreement: Too Little, Too Late?' (2017) Transnational Environmental Law, doi:10.1017/ S2047102517000280.

5. The 2010 Cancún Agreements acknowledged the link between climate change and human rights but they are not legally binding.

6. Maguire and Lewis note that draft texts contained stronger language, calling on states 'to ensure gender equality and the full and equal participation of women'. 
litigation. ${ }^{7}$ For the same reason, paragraph 52 of the Paris Conference of the Parties (COP) Decision explicitly excludes compensation and liability for loss and damage, rendering the inclusion of Article 8 in the Agreement at the insistence of developing countries something of a pyrrhic victory.

Despite reservations arising about the 'limited and weak' and 'timid' nature of the Agreement, ${ }^{8}$ the authors in this issue view the Agreement as a point of departure rather than foreclosure, and remain positive about the promotion and protections of human rights as a means of achieving climate justice. The four articles reflecting on the Paris Agreement advocate human-rights-based approaches to promote and protect the rights of women and local communities and the traditional knowledge and rights of indigenous peoples. In addition, the articles also link rights-based approaches to climate justice, a concept that is sidelined in the Paris Agreement and confined to a single disparaging reference in the Preamble to "the importance for some of the concept of "climate justice"".

The articles, which are not uncritical of the Agreement, reprise some of the issues discussed in Julia Dehm's analysis of the Paris Agreement in JHRE issue 8(2), such as the neoliberal, technocratic and managerialist orientation of the climate regime, and the impact this has had on the promotion and protection of human rights. ${ }^{9}$ The neoliberal character of the Paris Agreement and the REDD+ regime designed to conserve forests and reduce deforestation (also included in the fifth contribution, from Benjamin Meier et al.) inflects Kathleen Birrell and Lee Godden's article on 'Benefits and Sharing: Realizing Rights in REDD+', which analyses the degree to which benefit-sharing predicated upon increasingly formal forms of land ownership, access and tenure protects or undermines the rights of forest dwellers. Birrell and Godden note that indigenous peoples and local communities claim at least half the world's land on a customary basis but legally own just 10 per cent and have formal rights to use or manage an additional 8 per cent. They note that there is no agreed definition of benefit sharing in the REDD+ framework and argue that rights are diminished when they are conceived through the prism of benefit-sharing. The authors are sceptical that REDD+ can provide human rights protections through sustainable development in the ways envisaged by Sumudu Atapattu in this issue. They also argue that the "subtle re-articulation of community rights to the forests as "benefits" to be "shared" risks the commodification of a previously moral imperative. Indeed, the language of benefit-sharing increasingly appears to substitute for, and may ultimately frustrate, human rights aspirations ...' Like the Paris Agreement, the authors suggest,

7. The EU and the US viewed liability and compensation as a non-negotiable red line. F Harvey, 'Paris Climate Talks: Pressure Mounts on Countries to Produce Working Text', The Guardian, 4 December 2015 <https://www.theguardian.com/environment/2015/dec/04/paris-climate-talkspressure-mounts-on-countries-to-produce-working-text $>$ accessed 8 November 2017.

8. Maguire and Lewis and Savaresi respectively in this issue.

9. J Dehm, 'Post Paris Reflections: Fossil Fuels, Human Rights and the Need to Excavate New Ideas for Climate Justice' (2017) 8(2) Journal of Human Rights and the Environment 280-300. A recent report expresses concerns about corporate capture of the UNFCCC that threatens to undermine the Paris Agreement. Corporate Accountability et al., 'Polluting Paris: How Big Polluters are Undermining Global Climate Policy' <https://www.corporateac countability.org/wp-content/uploads/2017/10/PollutingParis_COP23Report_2017.pdf> accessed 2 November 2017. The report argues that market-based solutions to climate change that do little to reduce greenhouse gas emissions have become dogma at UNFCCC meetings despite strong reservations from many developing countries. 
REDD+ has the 'potential both to ameliorate and exacerbate existing causes of inequality for Indigenous peoples and forest-dwelling communities': it threatens to impose forms of development that import structural inequalities, which further disadvantage these communities by subordinating their needs and rights to corporate and sovereign interests. And like the Paris Agreement, it is far from clear that REDD+ will avert catastrophic climate change.

In her article entitled 'Traditional Knowledge and Climate Change: A New Legal Frontier?' Annalisa Savaresi notes that the Paris Agreement is also the first binding multilateral climate instrument that explicitly refers to traditional knowledge, which should guide adaptation policies under Article 7(5). Savaresi is hopeful, in the light of this, that the references to human rights in general and to the rights of indigenous peoples in particular constitute 'an opening to greater cross-fertilization and institutional cooperation' between international human rights law and the climate change regime.

Savaresi expresses similar apprehensions to those raised by Birrell and Godden about benefit-sharing and safeguards for the rights of indigenous peoples, including the need for clear prior informed consent,${ }^{10}$ and is concerned about the commoditization and monetization of tropical forests and traditional knowledge. However, Savaresi is more optimistic than Birrell and Godden that the linkage in the Paris Agreement between traditional knowledge and climate change could open a new legal frontier and help protect the rights of indigenous peoples, not least their right to culture.

Savaresi argues that international human rights law complements the protection of traditional knowledge against appropriation in international environmental instruments by imposing procedural obligations on states and provides remedies in domestic and, possibly, international law. She argues that international climate change law generally provides acceptable protection for traditional knowledge but is inadequate in relation to its promotion 'both in the assessment of and the design and implementation of climate change measures'. She suggests this could be strengthened by the adoption by the UNFCCC of guidelines on the use of traditional knowledge in scientific assessment and documentation processes.

Rowena Maguire and Bridget Lewis's article on 'Women, Human Rights and the Global Climate Regime' discusses the role of the UNFCCC in promoting gender equality. They note that the Paris Agreement does not engage with women's rights apart from the reference to gender equality and women's empowerment in the Preamble, although there are cursory references in Articles 7 and 11 to the need for adaptation and capacity-building to be gender-responsive. ${ }^{11}$ The authors justifiably contend that women's issues have too often been discussed when negotiations have stalled or as a form of gap filling, and that gender has been marginalized along with issues deemed 'less important' such as indigenous rights, the needs of small island states and human rights in general. ${ }^{12}$ Maguire and Lewis argue that gender balance (a weaker

10. See also J Dehm, 'Indigenous Peoples and REDD+ Safeguards: Rights as Resistance or as Disciplinary Inclusion in the Green Economy?' (2017) 7(2) Journal of Human Rights and the Environment 170-217.

11. There are several references to vulnerable groups and communities, although the term usually refers to states. Noticeably, women are amongst the vulnerable groups referred to in the Preamble.

12. Their point is valid despite the relative success of the Alliance of Small Island States in representing the interests of its members since the establishment of the UNFCCC, for example in the inclusion of Article 8 on loss and damage. 
concept than gender equality) in the UNFCCC is a necessary but insufficient precondition for the emergence of gender-responsive policies. They argue that despite 'the presence of women in key leadership positions, the coverage of gender and human rights in the Paris Agreement [is] nonetheless inadequate and progress on women's rights remains limited'. ${ }^{13}$ The authors acknowledge that women's participation in the regime is growing,${ }^{14}$ but stronger and more targeted action is required 'to address the underlying inequalities and patterns of discrimination which render women vulnerable'. They distinguish descriptive representation, the extent to which representatives reflect the objective characteristics of those they represent, from substantive representation that meaningfully meets the needs of its constituents. As Maguire and Lewis argue, the Agreement 'provides limited guidance for, and no structures to support' a gender perspective on climate change and human rights.

In her article entitled 'The Paris Agreement and Human Rights: Is Sustainable Development the "New Human Right?", Sumudu Atapattu argues that the inclusion of human rights in the Agreement is 'significant, if only for symbolic reasons', but also because it 'reminds states that human rights obligations are relevant and enforceable'. She argues that 'despite the rather half-hearted nature of the reference to climate justice in the Preamble, the explicit nature of the reference at least provides an additional hook upon which human rights advocates can pin their claims'. Indeed, in Atapattu's view, 'far from being confined to the Preamble, human rights underpin the entire Agreement as an integral component of sustainable development'. Atapattu maintains that the 15 references in the Paris Decision and Agreement to sustainable development provide an opening through which human rights can be read into the instrument as a whole.

Atapattu's ambitious argument is based upon the contention that sustainable development has come of age with the unanimous adoption by the UN General Assembly of the Sustainable Development Goals prior to the Paris Agreement. She argues that human rights 'are an integral component of sustainable development', and that the references to sustainable development in the Agreement 'must, by implication, be read as including human rights'. The need to smuggle human rights into the Paris Agreement in this way highlights, however, the absence of clear and enforceable obligations. Moreover, reading human rights into every aspect of the agreement potentially dilutes their potency. Atapattu herself acknowledges that the concept of sustainable development lacks clarity and that its liberal use throughout the Agreement may be because it 'is too vague to offer meaningful avenues of redress to victims of human rights violations'.

Atapattu's argument relies upon the assumption that sustainable development is a binding principle of international environmental law that imposes clear obligations on states. ${ }^{15}$ Atapattu argues that sustainable development is an erga omnes obligation even as she acknowledges that the dominant current economic model 'rewards unsustainable exploitation and consumption of resources'. If sustainability is recognised

13. Gender balance was discussed at COP 23: UNFCCC, Achieving the goal of gender balance, FCCC/TP/2017/8, 26 October 2017 <http://unfccc.int/resource/docs/2017/tp/08.pdf> accessed 16 November 2017.

14. It is a recognized objective of the UNFCCC, and the Women and Gender Constituency, established in 2009, is one of nine stakeholder groups in the UNFCCC.

15. Sands asserts that there "can be little doubt that the concept ... has entered the corpus of international customary law', P Sands, Principles of International Environmental Law (CUP, Cambridge 2003), 254. 
as a norm of international law, she argues, the pursuit of states' development policies is no longer a matter of sovereign prerogative but essentially the common concern of humankind.

The article by Benjamin Meier, Ipsita Das and Pamela Jagger, 'A "Burning Opportunity" for Human Rights: Using Human Rights as a Catalyst for Policies to Mitigate the Health Risk of Household Air Pollution', discusses the harms resulting from traditional cooking and heating technologies associated with energy poverty. Household air pollution threatens the right to health of individuals most vulnerable to a range of other climatic harms exacerbated by underdevelopment, weak infrastructure and low adaptive capacity. The authors focus on women's and children's rights, and call for a rights-based approach to address gender-based forms of disempowerment that deny many women control over their home environments and undermine their right to health. Alleviating energy poverty, argue the authors, is a key component of the Sustainable Development Goals. In addition, the argument offered by Meier et al. implicitly draws attention to the provisions in the Paris Agreement on technology transfer and capacity-building, and to wider questions concerning funding for adaptation and mitigation.

The articles in this issue offer, then, some innovative approaches designed to overcome the limitations of the Paris Agreement through rights-based approaches. They lament the failure of the conference of the parties to impose binding human rights obligations on state parties, but offer hope that the inclusion of human rights has broken new ground that can be productively tilled in a variety of ways that may fulfil the hopes that the poor and vulnerable have placed in the Agreement.

Sam Adelman Associate Professor, School of Law, University of Warwick 